\title{
EXPERIMENTAL INVESTIGATION ON THE COMPRESSIVE STRENGTH OF PRESSED COMPOSITE EARTH BRICK
}

\author{
M Prasanth ${ }^{1}$, Rejith Thomas $^{2}$, S Sandana Socrates ${ }^{3}$, S Sasi Kumar ${ }^{4}$, S S Manu ${ }^{5}$ \\ ${ }^{1} U G$ scholar, Department of civil engineering, Valliammai Engineering College, India \\ ${ }^{2} U G$ scholar, Department of civil engineering, Valliammai Engineering College, India \\ ${ }^{3} U G$ scholar, Department of civil engineering, Valliammai Engineering College, India \\ ${ }^{4} U G$ scholar, Department of civil engineering, Valliammai Engineering College, India \\ ${ }^{5}$ Assistant Professor, Department of civil engineering, Valliammai Engineering College, India
}

\begin{abstract}
Earth block is a construction material made primarily from soil. Compressed earth blocks have been widely used to construct many older structures which was found more economical. The present study involves the use of different admixtures which can improve the compressive strength of the pressed composite earth brick. As soil is abundant in nature, the compressed earth bricks can be manufactured in large quantity. By using this method, buildings of uniform component sizes can be made which leads to faster construction with lesser cost. The surface of building can be finished with clay mortar or cement mortar.
\end{abstract}

Keywords:- compression, brick, mould, economical

\section{INTRODUCTION}

The history of civilization is synonymous to the history of masonry. Man's first civilization, which started about 6000 years ago, was evident from the remains of the Mesopotamians masonry building units. During earlier days, the masonry units were constructed from any available material. The Mesopotamians used bricks, made from alluvial deposits of the nearby Rivers to build their cities. The provision of good quality housing is recognized as an important responsibility for the welfare of people in many country. For this reason, the building materials based on natural resources are often used. Earth can be used for construction of walls in various manner. But there are some undesirable properties such as reduction in strength when saturated with the water, wind erosion or driving out rain and poor dimensional stability. These problems can be eliminated by stabilizing the soil with a chemical agent such as fly ash, quarry dust, bagasse ash, lime powder, aggregates etc. These compressed earth bricks are unfired, uniform building blocks compressed from clay-retaining earth. It is suitable for application of load-bearing and non-load bearing walls. When a brick is compressed it loses nearly $30 \%$ of its volume due to the mechanical compression of the press driving out air pockets, aligning wet clay particles and compacting the clay around the soil particles. Normal concrete brick produces more $\mathrm{Co}_{2}$, which can be completely eliminated in CEB as it involves no burning. A simple manual press can produce $1000-1500$ bricks per day. For large scale production and more consistent quality, motorized or hydraulic machines are preferred.

The standard size of our compressed earth brick was adopted as $200 \mathrm{~mm} \times 100 \mathrm{~mm} \times 100 \mathrm{~mm}$.

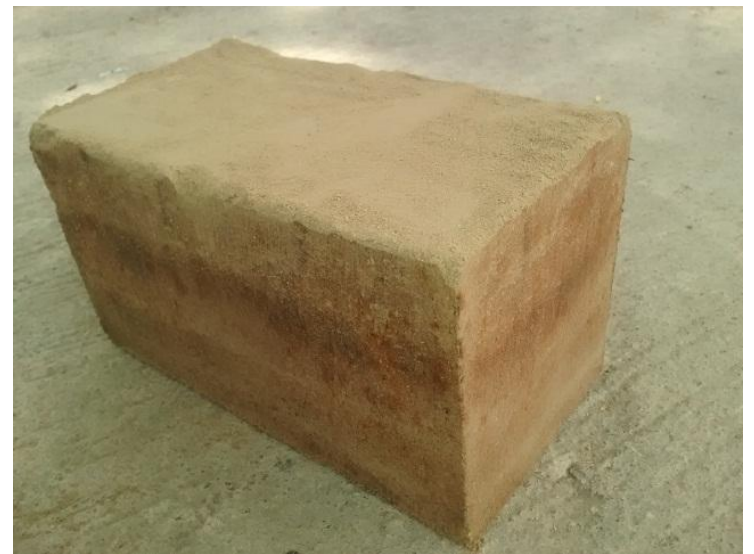

Fig 1 Sample of Brick

\section{Advantages:}

- In many places, earth (clay and silt soil) is easily available in its natural form at 1 to $2 \mathrm{~m}$ under the fertile top layer. Earth is a locally available material which reduces transportation cost.

- The uniformity of blocks can result in less waste, simplifies construction and reduces both labour and material cost. These bricks can store heat well and can give it off again, so that the temperature fluctuations are less.

- Earth emits no hazardous gases or substances into the interior atmosphere. It acts as fire resistance and sound insulation material.

- It is easy to produce and can be used after the instant it has been manufactured which means there is no need to wait for curing or drying 


\section{MATERIALS}

\subsection{Fly Ash}

Fly ash, also known as flue-ash, is one of the residues generated during combustion of coal. Use of fly ash in CEB reduces greenhouse gases and slows down global warming. Fly ash added CEB exhibits excellent physiochemical and mechanical properties including low density, negligible shrinkage, thermal stability, fire and chemical resistance than conventional clay bricks.

\subsection{Lime}

The experimental study on use of lime in CEB has brought out the effectiveness of lime in improving the long-term build-up of strength better than using cement alone. It was observed that bricks prepared with optimum quantity of lime with small amount of cement has led to continuous buildup of strength even beyond 2 years.

\subsection{Bagasse Ash}

Bagasse ash is an industrial waste which is used as fuel in the same sugarcane industry. The combustion yields ashes containing high amounts of silicon and aluminium oxides as main components. This enables them to use as a cementreplacing materials in concrete industry. These ashes are mixed with compressed earth brick to study its behavior of compressive strength.

\subsection{Coarse and Fine Aggregate}

Coarse aggregate of size passing through $10.7 \mathrm{~mm}$ and retained on $6.36 \mathrm{~mm}$ and fine aggregate of size passing through $4.75 \mathrm{~mm}$ and retained on $2.36 \mathrm{~mm}$ is replaced with earth material to increase its compressive strength.

\section{PRODUCTION PROCESS}

In this section the process involved in the production of brick is described, which involves compression method.

- $\quad$ The earth brick can be produced by the processes like manual presses, thermal presses \& solar presses. We adopted manual presses that need 15 tons of compression load to manufacture single material

- Usually for compressed earth block requires impact load for making the material as solid one. But we choose gradual loading for making bricks.

- We have prepared a metal type of mould for earth brick manufacturing that weigh around $30 \mathrm{~kg}$ and it consumes less cost for that preparation.We can easily dismantle the mould after the application of load and so preparation is precise.

\section{STEPS INVOLVED}

1. First the earth material is excavated at a depth of $3 \mathrm{~m}$ from the top surface of earth to avoid the presence of organic materials \& wastes.

2. The excavated earth was dried, made into fine particles and then it was sieved through various IS sieves of size $1.18 \mathrm{~mm}, 600 \mu, 300 \mu$.
3. Soil test was made on the sieved earth material in order to find the nature and characteristics of it and was found that it belong to organic type of clay soil.

4. At the initial part, earth material weighing $5 \mathrm{~kg}$ was taken and moisture content of $10-12 \%$ was added inorder to obtain the binding property.

5. Then the whole mixture was filled layer by layer into the mould and compaction is done with the help of Tshaped hammer at each layer to maintain the standard height of the brick after the application of load.

6. The top $2 \mathrm{~cm}$ of the brick mould was left free and the whole set up was kept in the Compression Testing Machine (CTM).Then the load was applied gradually up to $150 \mathrm{kN}$ which will give $30 \%$ volume reduction of earth brick.

7. Then it is demoulded and the brick is tested for its compressive strength.

\section{TEST ON SOIL}

There are different types of soil test conducted to study the nature of soil and its characteristics

- Specific gravity test

- Sieve analysis test

\subsection{Specific Gravity Test}

Specific gravity test is used to determine the soil properties like void ratio, degree of saturation. Specific gravity $G$ is defined as the ratio of the weight of a given volume of material to the weight of an equal volume of water (at $20^{\circ}$ C). From the specific gravity of soil using pycnometer, the value of $\mathrm{G}$ is 2.40 . So it comes under the organic type of soil.

Table 1: specific gravity test results

\begin{tabular}{|l|l|l|l|l|}
\hline S.No & $\begin{array}{l}\text { SAMPLE } \\
\text { DESCRIPTI } \\
\text { ON }\end{array}$ & $\begin{array}{l}\text { TRIAL } \\
1 \mathrm{~W}(\mathrm{~kg})\end{array}$ & $\begin{array}{l}\text { TRIAL } \\
2 \mathrm{~W} \\
(\mathrm{~kg})\end{array}$ & $\begin{array}{l}\text { AVERAG } \\
\text { EVALUE( } \\
\mathrm{kg})\end{array}$ \\
\hline 1 & $\begin{array}{l}\text { Wt. of empty } \\
\text { bottle(w1) }\end{array}$ & 0.659 & 0.659 & 0.659 \\
\hline 2 & $\begin{array}{l}\text { Wt. of bottle } \\
+ \text { soil(W2) }\end{array}$ & 1.127 & 1.163 & 1.145 \\
\hline 3 & $\begin{array}{l}\text { Wt. of bottle } \\
+\quad \text { soil }+ \\
\text { water(W3) }\end{array}$ & 1.648 & 1.687 & 1.69 \\
\hline 4 & $\begin{array}{l}\text { Wt. of bottle } \\
+ \text { water(W4) }\end{array}$ & 1.404 & 1.404 & 1.404 \\
\hline $\begin{array}{l}\text { Specific gravity G }=(\mathrm{W} 2-\mathrm{W} 1) /((\mathrm{W} 2-\mathrm{W} 1)- \\
(\mathrm{W} 3-\mathrm{W} 4))=(1.145-0.659) /((1.145-0.659)-\end{array}$ & $\begin{array}{l}2.40(\mathrm{no} \\
\text { unit })\end{array}$ \\
\hline
\end{tabular}

\subsection{Sieve Analysis Test}

Table 2: Finess modulus test result

\begin{tabular}{|l|l|l|l|l|}
\hline IS & WT.OF & $\%$ WT. & CUMUL & $\%$ \\
SIEVE & SOIL & RETAINED & ATIVE & FINE \\
& $\begin{array}{l}\text { RETAI } \\
\text { NED }\end{array}$ & & $\begin{array}{l}\text { PERCE } \\
\text { NTEGE }\end{array}$ & \\
\hline $4.75 \mathrm{~mm}$ & 0 & 0 & 0 & 100 \\
\hline $2.36 \mathrm{~mm}$ & 0 & 0 & 0 & 100 \\
\hline
\end{tabular}




\begin{tabular}{|l|l|l|l|l|}
\hline $1.18 \mathrm{~mm}$ & 0 & 0 & 0 & 100 \\
\hline 600 & 0.079 & 15.8 & 15.8 & 84.2 \\
\hline 300 & 0.182 & 36.4 & 52.2 & 47.8 \\
\hline 180 & 0.103 & 20.6 & 72.8 & 27.2 \\
\hline 150 & 0.034 & 6.8 & 79.6 & 20.4 \\
\hline 75 & 0.060 & 12 & 91.6 & 8.4 \\
\hline Pan & 0.032 & 6.4 & 98 & 2 \\
\hline
\end{tabular}

Fineness modulus of fine aggregate $=$ cumulative $\quad$ weight retained $/ 100=2$.

From the sieve analysis test, fineness modulus is found to be 2.0 and it is a fine aggregate (fine clay soil)

Table3: specific gravity values

\begin{tabular}{|l|l|}
\hline Type of soil & Specific gravity range \\
\hline Fine Aggregate & $2.63-2.67$ \\
\hline Silt & $2.65-2.7$ \\
\hline Clay \& Silt & $2.67-2.9$ \\
\hline Organic Soil & $<=2.4$ \\
\hline
\end{tabular}

\section{TYPE OF LOAD APPLIED TO THE MOULD}

The source for application of load is CTM which has a maximum capacity of 200 ton. As per literature, for the preparation of compressed earth block there are three kinds of loading such as

1. Manual press (10 ton)

2. Thermal press (15 ton)

3. Solar press (30 ton)

Here we choose manual method of applying load gradually through CTM up to $150 \mathrm{kN}$.

\section{MOULD PREPARATION}

The material for preparing mould involves MS bar of thickness $6 \mathrm{~mm}, 8 \mathrm{~mm}$ and $10 \mathrm{~mm}$. The mould contains base plate, side plate, angle sections and clamp to hold the mould. The angle sections are connected to the base plate by using dowel bars inorder to maintain its alignment.

Dimension of plate are as follows:

1. Base plate $-300 \mathrm{~mm} \times 400 \mathrm{~mm} \times 6 \mathrm{~mm}$

2. Side plate

a.) $200 \mathrm{~mm} \times 160 \mathrm{~mm} \times 8 \mathrm{~mm}$

b.) $100 \mathrm{~mm} \times 160 \mathrm{~mm} \times 8 \mathrm{~mm}$

3. Angle section

a.) $80 \mathrm{~mm} \times 160 \mathrm{~mm} \times 8 \mathrm{~mm}$

b.) $80 \mathrm{~mm} \times 80 \mathrm{~mm} \times 8 \mathrm{~mm}$

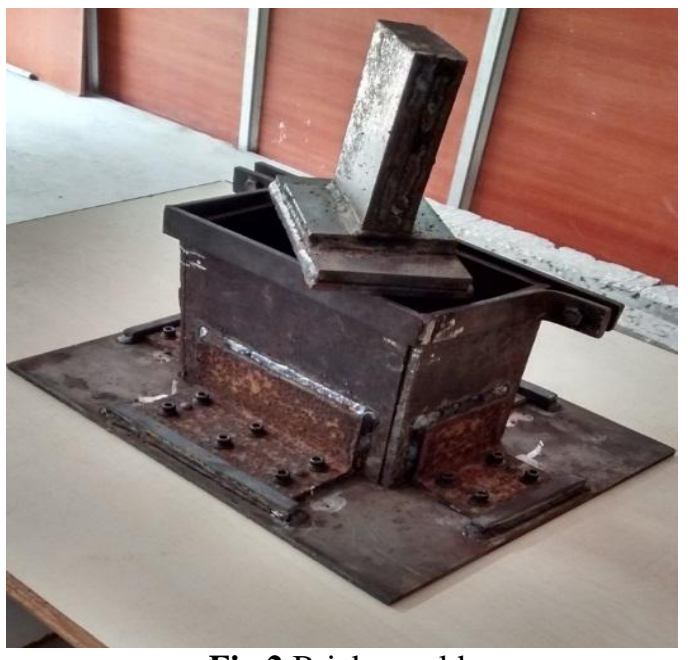

Fig 2 Brick mould

\subsection{Cost Analysis}

The following costs were involved in the production of a

Table 4: Cost involved for a brick

\begin{tabular}{|l|l|l|}
\hline S.NO. & ITEMS & COST(Rs.) \\
\hline 1 & Soil & 52.40 \\
\hline 2 & Lime & 25 \\
\hline 3 & $\begin{array}{l}\text { Cement } \\
\text { (per kg) }\end{array}$ & 7.5 \\
\hline 5 & Coarse aggregate & 40 \\
\hline 6 & $\begin{array}{l}\text { Fly ash } \\
\text { (per ton) }\end{array}$ & 200 \\
\hline 7 & $\begin{array}{l}\text { Baggase } \\
\text { (per ton) }\end{array}$ & 2000 \\
\hline 8 & Brick Mould & 2000 \\
\hline
\end{tabular}

\section{COMPRESSION STRENGTH TEST ON}

\section{BRICK}

Compression strength on compressed earth brick material can be tested by using same CTM (Compression Testing Machine). As per literature, generally it must have a maximum compression strength of $2 \mathrm{~N} / \mathrm{mm}^{2}$. We have obtained several strength for brick which were more or less equal to the previous value $\left(2 \mathrm{~N} / \mathrm{mm}^{2}\right)$. The different values of all the bricks are displayed below.

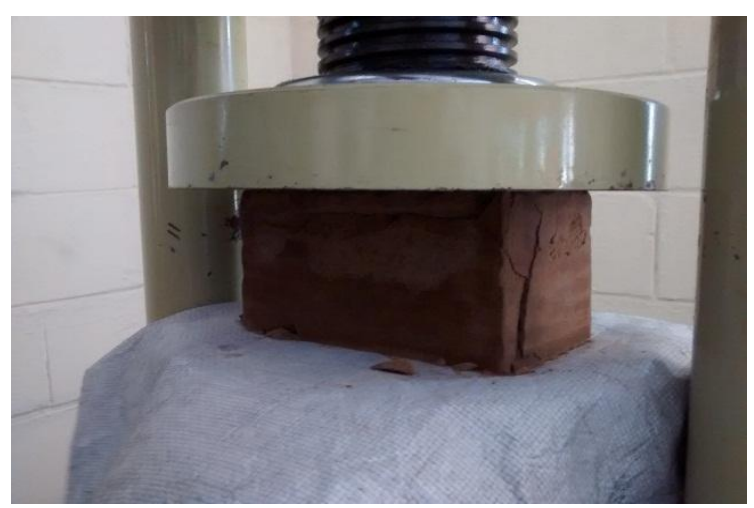

Fig 3 Crushing of brick sample 


\subsection{Analysis of Earth Brick}

$>\quad$ Based on grain size

We have made total of 20 bricks within short period and for each brick we have used different admixtures at different proportion depends on our strength requirement. We have also faced problem like failure brick while demoulding and two bricks were failed.

The graph mentioned below explains the strength comparison of compressed earth brick based on grain size of sieves

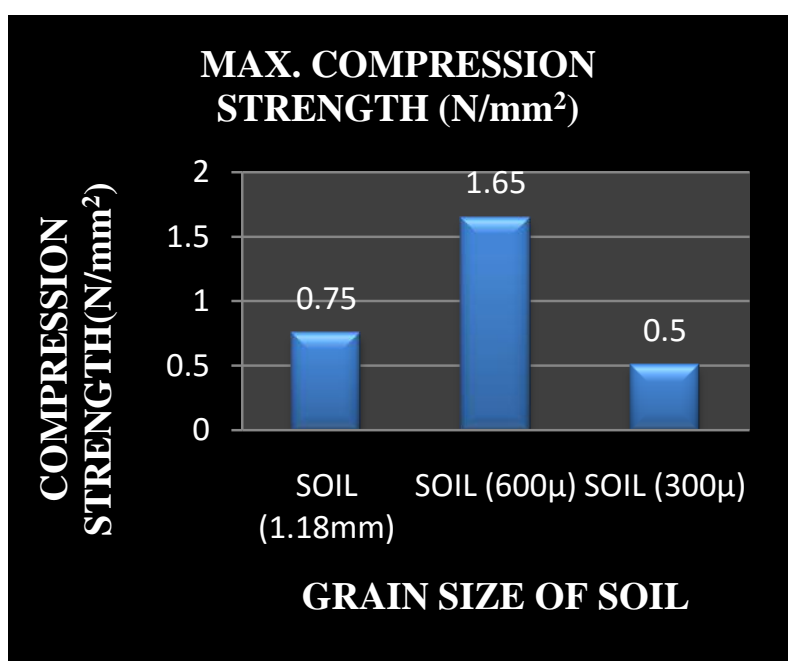

Fig 4 Compressive strength based on different grain size

Experiments were done on all the three sieves and several bricks were made using the above sieves. But the compression strength of each bricks varied depends on the grain size. The different values are obtained for each bricks and maximum compression strength value is noted and plotted as shown above. From the value got through the above graph we can conclude that the soil that passes through $600 \mu$ sieve has the higher strength than $1.18 \mathrm{~mm} \& 300 \mu$ sieves.

Hence compression strength of earth brick can attain a maximum values by using $600 \mu$ sieve.

\section{$>\quad$ Based on admixtures added}

We added several admixtures like lime, jaggery, cement, coarse aggregate, fly ash, bagasse ash \& quarry dust to study the behavior of compression strength of earth brick \& each admixtures were added in different proportion in order to find the maximum strength

Each brick that was made using admixtures shows different results of compression strength and maximum strength was found by using cement. But cement is eco- friendly for our project $\&$ hence we adopted for alternate source like lime and bagasse.

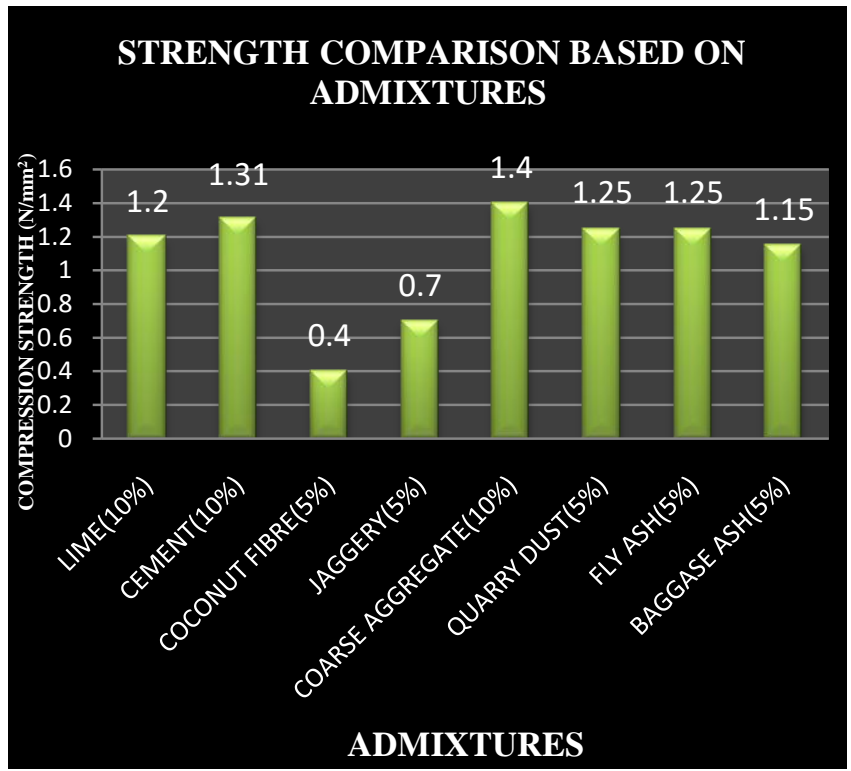

Fig 5 Strength comparison based on different admixtures

Hence compression strength of earth brick can attain a maximum values by using cement aggregate $\&$ fly ash.

\section{CONCLUSION}

From the above experimental studies, fly ash gives maximum compression strength of $1.25 \mathrm{~N} / \mathrm{mm} 2$ at $5 \%$ and $10 \%$. Coarse aggregate gives maximum compression strength of $1.4 \mathrm{~N} / \mathrm{mm} 2$ at $10 \%$. Quarry dust gives maximum compression strength of $1.25 \mathrm{~N} / \mathrm{mm} 2$ at $5 \%$. Bagasse ash gives maximum compression strength of $1.15 \mathrm{~N} / \mathrm{mm} 2$ at $5 \%$. But from the grain size of soil, the soil passing through $600 \mu$ gives better results compared to other grain size. Soil of $600 \mu$ gives maximum compression strength of 1.65 $\mathrm{N} / \mathrm{mm} 2$ when no other admixtures is added to it.

\section{REFERENCES}

[1] Hubert guillaud et al, "Compressed Earth Blocks: Manual of Design and Construction" - "Manual of design and construction" - 1995-Vol. 2- ISBN 3-52802080-6.

[2] Fetra Venny Riza et al, "Preliminary Study of Stabilized Earth Brick (CSEB)"- "Australian Journal of Basic and Applied Sciences", -Vol 5: 6-12, 2011, ISSN 1991-8178

[3] Baba Shehu Waziri et al, "Properties of Compressed Stabilized Earth Blocks (CSEB) For Low-Cost Housing Construction" - "International Journal of Sustainable Construction Engineering \& Technology (ISSN: 2180-3242) - Vol 4, No 2, 2013

[4] Batu Pahat et al, "Development of a Strength Prediction Model for Green Compressed Stabilized Earth bricks" - "Journal of Sustainable Development" - Vol. 3, No. 3; September 2010.

[5] Esther Obonyo et al, " Durability of Compressed Earth Bricks: Assessing Erosion Resistance Using the Modified Spray Testing" - "International Journal on Science and Technology" - Vol 2 No 9 November 2010 . 